\title{
[TI2Zn(ADC)2(H2O)2]: the first coordination polymer with acetylenedicarboxylate (ADC2-) as bridging ligand containing two different metal ions
}

\begin{tabular}{|r|l|}
\hline Journal: & Zeitschrift für Anorganische und Allgemeine Chemie \\
\hline Manuscript ID: & zaac. 200900428 \\
\hline Wiley - Manuscript type: & Communication \\
\hline Date Submitted by the \\
Author: & $06-S e p-2009$ \\
\hline Complete List of Authors: & $\begin{array}{l}\text { Ruschewitz, Uwe; Universitaet zu Koeln, Department fuer Chemie } \\
\text { Ahlers, Ruth; Universitaet zu Koeln, Department fuer Chemie }\end{array}$ \\
\hline Keywords: & $\begin{array}{l}\text { Acetylenedicarboxylate, Coordination Polymer, Crystal Structure, } \\
\text { Thallium, Zinc }\end{array}$ \\
\hline
\end{tabular}

\section{S ScholaroNE \\ Manuscript Central}


[a] Department of Chemistry, University of Cologne, Greinstraße 6, D-50939 Köln (Germany) Fax: +49-(0)-221-470-3933

E-mail: Uwe.Ruschewitz@uni-koeln.de

\section{Introduction}

Coordination polymers, especially their porous exponents frequently named MOFs (metal-organic framework) [1], are in the focus of many research groups world-wide. Their easy synthetic accessibility as well as their potential applications [2] have mainly caused this interest. But also the perspective to construct or even to "design" new solids starting from simple building blocks like metal ions or metal-oxo clusters and organic polyfunctional ligands [3] is attractive and another reason for the ongoing interest in coordination polymers. But, despite some spectacular achievements [4], the real design, i.e. the synthesis of a new coordination polymer with an a priori given structural arrangement is in most cases difficult or even impossible.

In our work we have mainly concentrated on acetylenedicarboxylate $\left(\mathrm{ADC}^{2-}\right)$, as this is one of the simplest linker, which can be used for the synthesis of coordination polymers. It consists of a rigid carbon backbone with two coordinating carboxylate groups. Thus, it is predestined to investigate the underlying mechanisms and interactions that lead to the formation of a specific structural arrangement. The first coordination compounds with $\mathrm{ADC}^{2-}$ were published by Robl [5]. In recent years we have been able to synthesize several hydrous [6] and anhydrous [7] coordination polymers with $\mathrm{ADC}^{2-}$ as bridging ligand, as well as compounds with pyridine or 4,4'-bipyridine as additional ligand [8]. Very recently it was shown that $\mathrm{ADC}^{2-}$ can also be used to synthesize MOF-type coordination polymers [9]. In this work we will present the first coordination polymer with $\mathrm{ADC}^{2-}$ that contains two different metal ions, namely $\mathrm{Tl}^{+}$and $\mathrm{Zn}^{2+}$.

\section{Results and Discussion}

${ }_{\infty}^{3}\left[\mathrm{Tl}_{2} \mathrm{Zn}(\mathrm{ADC})_{2}\left(\mathrm{H}_{2} \mathrm{O}\right)_{2}\right](\mathbf{1})$ crystallizes in triclinic space group $\mathrm{P} \overline{1}$ (no. 2) with $\mathrm{Z}=1$. ORTEP diagrams of the coordination spheres around $\mathrm{Zn}^{2+}$ and $\mathrm{Tl}^{+}$are shown in Figure 1, some selected interatomic distances and angles are given in Table 2. For $\mathrm{Zn}^{2+}$, a slightly distorted octahedral coordination is found, formed by four oxygen atoms of four different $\mathrm{ADC}^{2-}$ ligands and two oxygen atoms of two water molecules. The $\mathrm{Zn}-\mathrm{O}$ distances to oxygen atoms of the water molecules (O5) are distinctively shorter than those to oxygen atoms of the $\mathrm{ADC}^{2-}$ ligands (s. Table 2). But they are in the range found for $\left.{ }_{\infty}^{3}\left[\mathrm{Zn}(\mathrm{ADC})\left(\mathrm{H}_{2} \mathrm{O}\right)_{2}\right][6 \mathrm{f})\right](\mathrm{Zn}-\mathrm{O}=$ $206.7-215.1 \mathrm{pm})$, which also exhibits a slightly distorted octahedral $\mathrm{ZnO}_{6}$ coordination with two water molecules in trans positions.

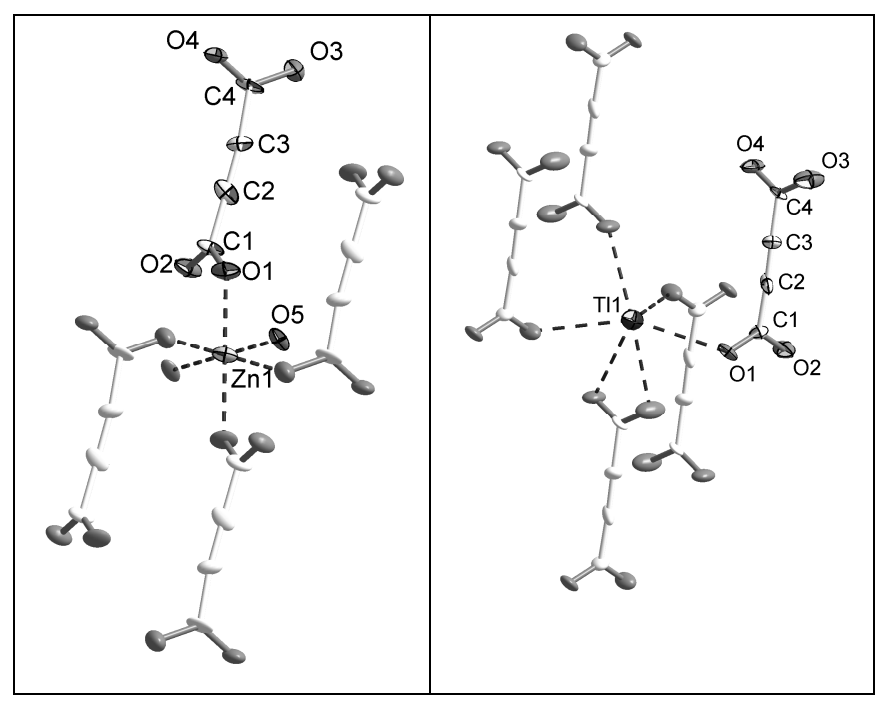

Figure 1. ORTEP diagrams of the coordination spheres around $\mathrm{Zn}$ (left) and Tl (right) in ${ }_{\infty}^{3}\left[\mathrm{Tl}_{2} \mathrm{Zn}(\mathrm{ADC})_{2}\left(\mathrm{H}_{2} \mathrm{O}\right)_{2}\right]$ (1) showing $50 \%$ probability thermal ellipsoids and the atom-numbering scheme. Zn$\mathrm{O}$ and $\mathrm{Tl}-\mathrm{O}$ bonds are drawn as broken lines. 
The coordination sphere around $\mathrm{Tl}^{+}$is less symmetric. Using the formalism of Brese and O'Keeffe [10], a valence $\mathrm{v}_{\mathrm{i}}=$ 0.79 is calculated taking into account six Tl-O distances < $321 \mathrm{pm}$. Adding two next-nearest neighbour distances given in Table 2 , the valence is only slightly increased $\left(v_{i}=0.84\right)$ so that only six nearest neighbour distances with $\mathrm{Tl}-\mathrm{O}<321$ pm will be considered in the following. These oxygen atoms belong to five different $\mathrm{ADC}^{2-}$ ligands with one carboxylate group coordinating in a chelating mode. The coordination sphere of $\mathrm{Tl}^{+}$is shown in Figure 1 (right). Apparently, one hemisphere of its coordination sphere is unoccupied, obviously accommodating a stereochemically active lone pair of $\mathrm{Tl}^{+}$. Similar results were obtained for $\mathrm{Tl}_{2} \mathrm{ADC}$ [7e)], also the Tl-O distances are very similar in both compounds $\left(\mathrm{Tl}_{2} \mathrm{ADC}\right.$ : $\left.\mathrm{Tl}-\mathrm{O}=263.5-327.1 \mathrm{pm}\right)$. It is noteworthy that the water molecule (O5) is not part of the inner coordination sphere of $\mathrm{Tl}^{+}(\mathrm{Tl}-\mathrm{O} 5=360 \mathrm{pm})$. It is coordinating only to $\mathrm{Zn}^{2+}$.

With respect to $\mathrm{ADC}^{2-} \mathrm{O} 1$ coordinates to $\mathrm{Tl}$ and $\mathrm{Zn}, \mathrm{O} 2$ to two $\mathrm{Tl}$ atoms. Carboxylate group $\mathrm{O} 3-\mathrm{C} 4-\mathrm{O} 4$ coordinates in a four-dentate mode bridging two $\mathrm{Tl}$ - one in a chelating mode - and one $\mathrm{Zn}$ atom. The distances and angles within the $\mathrm{ADC}^{2-}$ ligand are in the expected range, although the accuracy of these values is modest due to the high scattering power of $\mathrm{Tl}$.

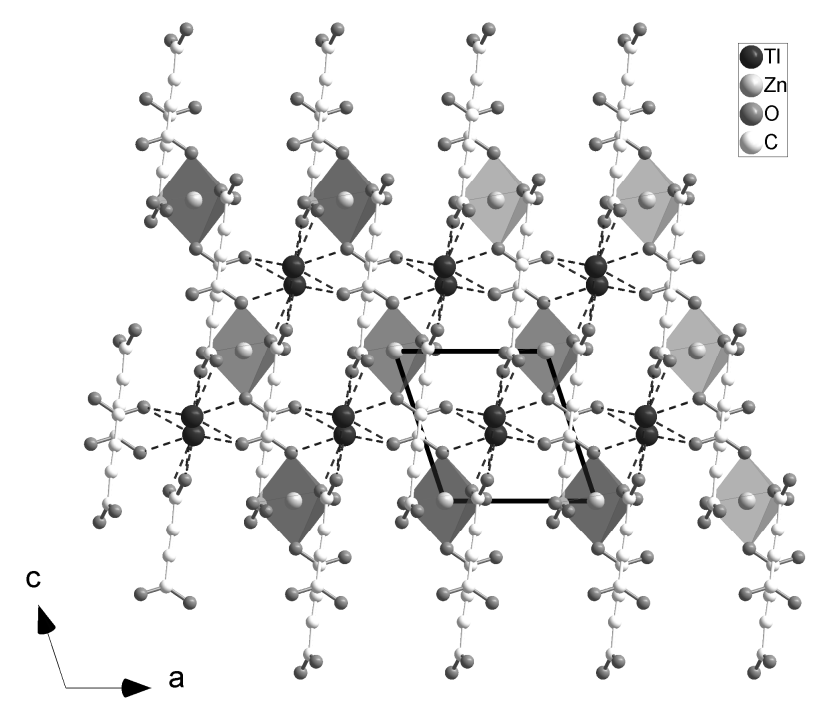

Figure 2. Packing diagram of ${ }_{\infty}^{3}\left[\mathrm{Tl}_{2} \mathrm{Zn}(\mathrm{ADC})_{2}\left(\mathrm{H}_{2} \mathrm{O}\right)_{2}\right]$ (1) in a projection along [010]. $\mathrm{ZnO}_{6}$ octahedra are emphasized and $\mathrm{Tl}-\mathrm{O}$ bonds are drawn as broken lines.

The packing diagram of the crystal structure of $\mathbf{1}$ is shown in Figure 2. $\mathrm{Tl}$ and $\mathrm{Zn}$ atoms are connected by the $\mathrm{ADC}^{2-}$ ligands to form a 3D network structure. Additionally, hydrogen bonds are formed between water molecule $\mathrm{O} 5$ and oxygen atoms of the carboxylate groups $(\mathrm{O} 5 \cdots \mathrm{O}=274-284$ pm). Also small channels parallel to [010] can be seen in Figure 2. These channels are not empty; most likely they accommodate the lone pair of $\mathrm{Tl}^{+}$.

In an alternative description the crystal structure of $\mathbf{1}$ can be understood as consisting of ${ }_{\infty}^{1}\left[\mathrm{Zn}(\mathrm{ADC})_{4 / 2}\left(\mathrm{H}_{2} \mathrm{O}\right)_{2}\right]^{2-}$ chains, which are connected by $\mathrm{Tl}^{+}$ions to form a 3D network structure.
Table 1. Details of single crystal structural analysis of ${ }_{\infty}^{3}\left[\mathrm{Tl}_{2} \mathrm{Zn}(\mathrm{ADC})_{2}\left(\mathrm{H}_{2} \mathrm{O}\right)_{2}\right](\mathbf{1})$.

\begin{tabular}{ll}
\hline & ${ }_{\infty}^{3}\left[\mathrm{Tl}_{2} \mathrm{Zn}(\mathrm{ADC})_{2}\left(\mathrm{H}_{2} \mathrm{O}\right)_{2}\right](\mathbf{1})$ \\
\hline Formula & $\mathrm{C} 8 \mathrm{H} 4 \mathrm{O} 10 \mathrm{Tl} 2 \mathrm{Zn}$ \\
Crystal size & $0.2 \times 0.2 \times 0.2 \mathrm{~mm}$ \\
Crystal color & Colorless \\
Diffractometer, $\lambda$ & Stoe IPDS I, $71.073 \mathrm{pm}$ \\
Temperature & $293 \mathrm{~K}$ \\
Space group; $\mathrm{Z}$ & $\mathrm{P} \overline{1}, 1$ \\
Unit cell & $\mathrm{a}=728.9(2) \mathrm{pm}$ \\
& $\mathrm{b}=737.6(2) \mathrm{pm}$ \\
& $\mathrm{c}=751.1(2) \mathrm{pm}$ \\
& $\alpha=113.18(3)^{\circ}$ \\
& $\beta=95.22(3)^{\circ}$ \\
Volume & $\gamma=115.55(3)^{\circ}$ \\
Density calculated & $0.3179(2) \mathrm{nm}^{3}$ \\
$2 \theta_{\text {max }}$ & $3.835 \mathrm{Mg}^{3} \mathrm{~m}^{3}$ \\
Number of reflections: & $56.4^{\circ}$ \\
independent & \\
$\mathrm{F}^{2}>2 \sigma\left(\mathrm{F}^{2}\right)$ & 1422 \\
$\mu /$ mm & \\
$\mathrm{R} 1\left(\mathrm{~F}^{2}>2 \sigma\left(\mathrm{F}^{2}\right)\right)$ & 879 \\
$w \mathrm{R} 2($ all data $)$ & $27.20 \mathrm{~mm}^{-1}$ \\
GooF & 0.074 \\
Number of refined parameters & 0.196 \\
$\Delta \rho_{\min / \text { max }}$ & 0.93 \\
\hline
\end{tabular}

Table 2. Selected interatomic distances $(\mathrm{pm})$ and angles $\left(^{\circ}\right)$ in ${ }_{\infty}^{3}\left[\mathrm{Tl}_{2} \mathrm{Zn}(\mathrm{ADC})_{2}\left(\mathrm{H}_{2} \mathrm{O}\right)_{2}\right](\mathbf{1})$.

\begin{tabular}{clll}
\hline T11 - O3 & $270(2)$ & $\mathrm{C} 1-\mathrm{O} 1$ & $126(3)$ \\
$-\mathrm{O} 1$ & $288(2)$ & $\mathrm{C} 1-\mathrm{O} 2$ & $121(2)$ \\
$-\mathrm{O} 2$ & $292(2)$ & $\mathrm{C} 4-\mathrm{O} 3$ & $127(3)$ \\
$-\mathrm{O} 4$ & $300(2)$ & $\mathrm{C} 4-\mathrm{O} 4$ & $122(3)$ \\
$-\mathrm{O} 2$ & $301(2)$ & & \\
$-\mathrm{O} 4$ & $321(1)$ & $\mathrm{C} 1-\mathrm{C} 2$ & $143(3)$ \\
$-\mathrm{O} 1$ & $354(2)$ & $\mathrm{C} 2-\mathrm{C} 3$ & $124(3)$ \\
$-\mathrm{O} 5$ & $360(2)$ & $\mathrm{C} 3-\mathrm{C} 4$ & $146(3)$ \\
& & & \\
$\mathrm{Zn} 1-\mathrm{O} 5$ & $204(1) 2 \mathrm{x}$ & & \\
$-\mathrm{O} 3$ & $211(3) 2 \mathrm{x}$ & & \\
$-\mathrm{O} 1$ & $213(2) 2 \mathrm{x}$ & & \\
\hline $\mathrm{O} 1-\mathrm{Zn} 1-\mathrm{O} 3$ & $94.2(7) 2 \mathrm{x}$ & $\mathrm{O} 1-\mathrm{C} 1-\mathrm{C} 2$ & $115(2)$ \\
$\mathrm{O} 1-\mathrm{Zn} 1-\mathrm{O} 5$ & $94.0(6) 2 \mathrm{x}$ & $\mathrm{O} 2-\mathrm{C} 1-\mathrm{C} 2$ & $117(2)$ \\
$\mathrm{O} 3-\mathrm{Zn} 1-\mathrm{O} 5$ & $95.9(6) 2 \mathrm{x}$ & $\mathrm{O} 3-\mathrm{C} 4-\mathrm{C} 3$ & $118(2)$ \\
& & $\mathrm{O} 4-\mathrm{C} 4-\mathrm{C} 3$ & $118(2)$ \\
$\mathrm{O} 1-\mathrm{C} 1-\mathrm{O} 2$ & $128(2)$ & $\mathrm{C} 1-\mathrm{C} 2-\mathrm{C} 3$ & $178(2)$ \\
$\mathrm{O} 3-\mathrm{C} 4-\mathrm{O} 4$ & $124(2)$ & $\mathrm{C} 2-\mathrm{C} 3-\mathrm{C} 4$ & $174(2)$ \\
\hline
\end{tabular}

\section{Conclusions}

In summary, we have been able to synthesize the first example of a coordination polymer with $\mathrm{ADC}^{2-}$ as bridging ligand that contains two different metal ions, namely $\mathrm{Tl}^{+}$and $\mathrm{Zn}^{2+}$. The synthesis of such compounds is not straightforward, as in most cases the formation of "binary" (i.e. one metal and one bridging ligand) compounds or a mixture of both - here: $\left.\mathrm{Tl}_{2} \mathrm{ADC}[7 \mathrm{e})\right]$ and $\left.{ }_{\infty}^{3}\left[\mathrm{Zn}(\mathrm{ADC})\left(\mathrm{H}_{2} \mathrm{O}\right)_{2}\right][6 \mathrm{f})\right]-$ is preferred. That means, the synthetic conditions (solvent, 
temperature etc.) have to be adjusted such that the ternary compound crystallizes before the crystallization of the possible binary products starts. To our knowledge the synthesis of such ternary coordination polymers is not reported very often compared to numerous examples of binary compounds. Especially the synthesis of ternary porous coordination polymers seems to be worthwhile, as they should offer a great potential as ion exchanger.

It was observed that compounds containing a stereochemically active lone pair show an enhanced probability to crystallize in acentric space groups [11]. Actually, $\left.\mathrm{Tl}_{2} \mathrm{ADC}[7 \mathrm{e}), 12\right]$ and $\mathrm{Tl}_{4}(\mathrm{ADC})(\mathrm{oxa})$ (oxa $=$ oxalate) $[7 \mathrm{e})]$ were found to crystallize in acentric space groups, while ${ }_{\infty}^{3}\left[\mathrm{Tl}_{2} \mathrm{Zn}(\mathrm{ADC})_{2}\left(\mathrm{H}_{2} \mathrm{O}\right)_{2}\right]$ (1) crystallizes in centrosymmetric space group $\mathrm{P} \overline{1}$. Therefore more examples of coordination polymers with $\mathrm{Tl}^{+}$are necessary to evaluate the applicability of this observation.

\section{Experimental Section}

Caution!!! Thallium compounds are highly toxic. Therefore adequate safety precautions have to be used before handling thallium compounds.

Synthesis.

${ }_{\infty}^{3}\left[\mathrm{Tl}_{2} \mathrm{Zn}(\mathrm{ADC})_{2}\left(\mathrm{H}_{2} \mathrm{O}\right)_{2}\right](\mathbf{1})$ : In a beaker $0.063 \mathrm{~g}(0.5 \mathrm{mmol})$ $\mathrm{ZnCO}_{3}, 0.263 \mathrm{~g}(1 \mathrm{mmol}) \mathrm{Tl}\left(\mathrm{CH}_{3} \mathrm{COO}\right)$ and $0.114 \mathrm{~g}(1 \mathrm{mmol})$ $\mathrm{H}_{2} \mathrm{ADC}$ were dissolved in $4 \mathrm{~mL}$ demineralized water. The beaker was sealed with a perforated foil. After evaporation of the solvent at room temperature (approx. 8 days) colorless crystals precipitated, from which a single crystal suitable for a structure analysis was isolated. According to X-ray powder diffraction data (Huber G 670, $\mathrm{CuK} \alpha_{1}$ radiation) the sample is single-phase.

$\mathrm{X}$-ray single-crystal structure analysis.

Single crystals of 1 were isolated from the precipitate as described above and mounted in sealed glass capillary on a Stoe IPDS I single-crystal diffractometer $(\mathrm{T} \approx 293 \mathrm{~K}, \mathrm{MoK} \alpha$ radiation). For data collection and reduction the Stoe program package [13] was applied. The structural model was solved using SIR-92 [14] and completed using difference Fourier maps calculated with SHELXL-97 [15], which was also used for final refinement. All programs were run under the WinGX system [16]. All nonhydrogen atoms were refined anisotropically. Hydrogen atoms of the water molecule could not be located in the Fourier map and were therefore not included in the final refinement. More details of the structural analysis [17] are given in Table 1. Selected interatomic distances and angles are listed in Table 2.

\section{Acknowledgments}

We would like to thank Dr. Ingo Pantenburg and Ingrid Müller for collecting single-crystal X-ray diffraction data.

[1] H. Li, M. Eddaoudi, M. O’Keeffe, O.M. Yaghi, Nature 1999, 402, 276-279.

[2] U. Mueller, M. Schubert, F. Teich, H. Puetter, K. SchierleArndt, J. Pastré, J. Mater. Chem. 2006, 16, 626-636.

[3] B. Moulton, M.J. Zaworotko, Chem. Rev. 2001, 101, 16291658.

[4] M. Eddaoudi, J. Kim, N. Rosi, D. Vodak, J. Wachter, M. O’Keeffe, O. M. Yaghi, Science 2002, 295, 469-472.
[5] a) Ch. Robl. S. Hentschel, Z. Naturforsch. 1990, 45b, 14991502; b) Ch. Robl, S. Hentschel, Z. Anorg. Allg. Chem. 1990, 591, 188-194; c) Ch. Robl, S. Hentschel, Z. Anorg. Allg. Chem. 1991, 596, 149-155.

[6] a) F. Hohn, H. Billetter, I. Pantenburg, U. Ruschewitz, Z. Naturforsch. 2002, 57b, 1375-1381; b) I. Pantenburg, U. Ruschewitz, Z. Anorg. Allg. Chem. 2002, 628, 1697-1702; c) U. Ruschewitz, I. Pantenburg, Acta Crystallogr. 2002, C58, m483-m484; d) H. Billetter, F. Hohn, I. Pantenburg, U. Ruschewitz, Acta Crystallogr. 2003, C59, m130-m131; e) H. Billetter, I. Pantenburg, U. Ruschewitz, Z. Naturforsch. 2004, 59b, 903-909; f) I. Stein, U. Ruschewitz, Acta Crystallogr. 2005, E61, m2680-m2682.

[7] a) F. Hohn, I. Pantenburg, U. Ruschewitz, Chem. Eur. J. 2002, 8, 4536-4541; b) A. Schuy. I. Stein, U. Ruschewitz, Z. Kristallogr. 2005, Suppl. 22, 179; c) I. Stein, Ch. Näther, U. Ruschewitz, Solid State Sci. 2006, 8, 353-358; d) I. Stein, Dissertation 2008, Köln; e) R. Ahlers, U. Ruschewitz, Solid State Sci. 2009, 11, 1058-1064.

[8] a) I. Stein, M. Speldrich, H. Schilder, H. Lueken, U. Ruschewitz, Z. Anorg. Allg. Chem. 2007, 633, 1382-1390; b) I. Stein, U. Ruschewitz, Z. Anorg. Allg. Chem. 2009, 635, 914-919.

[9] a) J. Kim, B. Chen, T. M. Reineke, H. Li, M. Eddaoudi, D. B. Moler, M. O'Keeffe, O. M. Yaghi, J. Am. Chem. Soc. 2001, 123, 8239-8247; b) D. J. Tranchemontagne, J. R. Hunt, O. M. Yaghi, Tetrahedron 2008, 64, 8553-8557.

[10] N. E. Brese, M. O’Keeffe, Acta Crystallogr. 1991, B47, 192197.

[11] a) H.-S. Ra, K. M. Ok, P. S. Halasyamani, J. Am. Chem. Soc. 2003, 125, 7764-7765; b) K. M. Ok, P. S. Halasyamani, Angew. Chem. 2004, 116, 5605-5607; Angew. Chem. Int. Ed. 2004, 43, 5489-5491.

[12] A. Askarinejad, A. Morsali, J. Coord. Chem. 2007, 60, 19031912.

[13] Stoe, IPDS manual, Stoe \& Cie GmbH, Germany; X-Red 1.22, Stoe Data Reduction Program, Stoe \& Cie GmbH, Germany, 2001.

[14] A. Altomare, G. Cascarano, C. Giacovazzo, A. Gualardi, J. Appl. Crystallogr. 1993, 26, 343-350.

[15] G. M. Sheldrick, SHELXL-97: A program for crystal structure refinement, University of Göttingen, Germany, 1997; release 97-2.

[16] WinGX-Version 1.64.04, An Integrated System of Windows Programs for the Solution, Refinement and Analysis of Single Crystal X-Ray Diffraction Data, Department of Chemistry, University of Glasgow, 1997-2002; L. J. Farrugia, J. Appl. Crystallogr. 1999, 32, 837-838.

[17] Crystallographic data (excluding structure factors) for the structure reported in this paper have been deposited with the Cambridge Crystallographic Data Centre as supplementary publication no. CCDC-746532. Copies of the data can be obtained free of charge on application to CCDC, 12 Union Road, Cambridge CB2 1EZ, UK [fax.: (internat.) + 44 1223/336-033; e-mail: deposit@ccdc.cam.ac.uk]. 


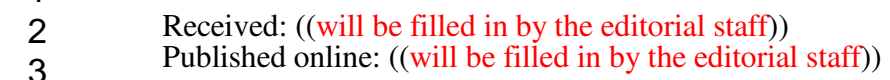

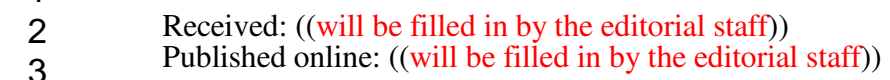


5

6
7

8

9 